\title{
Filtration and digestion responses of an elementally homeostatic consumer to changes in food quality: a predictive model
}

\author{
François Darchambeau
}

\begin{abstract}
Darchambeau, F. 2005. Filtration and digestion responses of an elementally homeostatic consumer to changes in food quality: a predictive model. - Oikos 111:
\end{abstract} $322-336$

In the study of the stoichiometric relationship between autotrophs and herbivores, attention has been largely focused on effects of the encountered mismatch between needs and supplies of an element on herbivore growth and ecosystem processes. Herbivore adaptation to poor food quality has rarely been investigated. This study presents a predictive model of feeding, assimilation, digestion and excretion of Daphnia facing a dietary deficiency in phosphorus. Biochemical compounds in the food were divided into phosphorous and non-phosphorus compounds. It was assumed that Daphnia is able to differently assimilate both types of compounds by regulation of target specific digestive enzymes. Feeding rate was regulated by optimal gut residence time of food particles, and assimilation efficiency by gut residence time and optimal secretion of both classes of gut enzymes. The model predicted the optimal strategy for a consumer facing an elementally imbalanced diet: (1) increase the ingestion rate, and (2) increase the secretion rate of both classes of gut enzymes. It resulted in decreased $\mathrm{C}$ and nutrient assimilation efficiencies, increased $\mathrm{C}$ feeding costs, and reduced growth rate. Sensitivity analysis showed that these predictions were qualitatively not influenced by parameter values. An alternative model was tested that includes an additive term allowing the direct excretion of $\mathrm{C}$ assimilated in excess. Results showed that this strategy is not optimal for the consumer growth rate. In conclusion, the model supports the hypothesis that carbon ingested in excess may generate energy that can be used to obtain more nutrients by increased feeding rate.

F. Darchambeau, Facultés Universitaires Notre-Dame de la Paix, URBO-Laboratory of Freshwater Ecology, Rue de Bruxelles 61, BE-5000 Namur, Belgium. Present address: Univ. du Québec à Trois-Rivières, GREA, CP 500, Trois-Rivières, Québec, Canada, G9A $5 H 7$ (francois_darchambeau@uqtr.ca).

Research in ecology has recently focused on the stoichiometry of the trophic relationship between autotrophs and herbivorous consumers, leading to a new discipline, ecological stoichiometry (Sterner and Elser 2002). This conceptual framework emerged from the evidence for homeostatic regulation of the elemental contents of many herbivores, and especially zooplankters (Hessen 1990, Andersen and Hessen 1991, Hessen and Lyche 1991, Sterner and Elser 2002). This elemental homeostasis of herbivores contrasts with observed variability in nutrient contents of primary producers
(Hessen and Andersen 1992, Elser et al. 2000, Schade et al. 2003). The mismatch encountered by zooplankters between their elemental needs and supplies provided by planktonic algae could lead to reduced somatic and population growth of herbivores (Hessen 1997, Sterner et al. 1998, Hessen and Faafeng 2000). This is particularly true for zooplankters of the genus Daphnia, which maintain high body proportion of phosphorus (P) whilst this element often limits phytoplankton growth in temperate lakes (Sterner and Hessen 1994). 
Some compensatory mechanisms to cope with this mismatch have been proposed and studied for Daphnia feeding on diets with varying C:P-ratio. Very low $\mathrm{P}$ release rates when Daphnia were fed on P-limited algae were reported (Lehman 1980, Olsen and Østgaard 1985, Van Donk et al. 1993). Respiration and extracellular excretion of $\mathrm{C}$ compounds have also been demonstrated as a means to dispose of $\mathrm{C}$ assimilated in excess from the food (Darchambeau et al. 2003). Moreover, assimilation from food of the deficient element may be improved. However, DeMott et al. (1998) observed that both C and $\mathrm{P}$ assimilation efficiencies of Daphnia fed with Pdeficient algae were reduced. Note that the reduction of $\mathrm{P}$ assimilation efficiency was lower than that for $\mathrm{C}$, leading to a more balanced C:P ratio of incorporated elements relative to the grazer demands.

Assimilation of elements from food is controlled by digestive enzymes secreted through the gut wall and by residence time into the gut of food particles. $\mathrm{C}$ and $\mathrm{P}$ are available from ingested biochemical compounds, such as proteins, lipids or carbohydrates, and are assimilated in slightly hydrolysed forms (amino acids, monosaccharides, ...), but not in the elemental form (if we exclude the known ability of Daphnia to incorporate inorganic P directly into its body from the surrounding water when that $\mathrm{P}$ is in very high concentration in the water, Parker and Olsen 1966). Some biochemical compounds are richer in $\mathrm{P}$ than others. In plants, $\mathrm{P}$ is found in nucleic acids (RNA and DNA), in P-lipids (essentially included in membranes, with e.g. lecithin), in P-esters (ATP, glucose 6-phosphate, etc.), and sometimes substantially in the form of polyphosphate (poly-Pi) chains (included in polyphosphate bodies; Twiss and Nalewajko 1992, Siderius et al. 1996). These compounds are present in various proportions, with poly-Pi, RNA and, for a short period, also ATP playing an important role in the storing of P (Melzer and Steinberg 1983). In young leaves, $\mathrm{P}$ is found in the proportion of poly-Pi 10, RNA 2, DNA 0.15, P-lipid 1.5, P-ester 10 on a weight basis (Bieleski 1973). Proteins and carbohydrates contain no or very few $\mathrm{P}$. The hydrolysis of these compounds into the gut lumen is controlled by the secretion of special gut enzymes (lipases, proteases, carbohydrases, nucleases, etc.). So, by regulation of the secretion of some specific enzymes, animals can probably, at least partly, control the assimilation of some specific elements.

Beside enzymatic regulation, another mechanistic way to improve the assimilation efficiency of the limiting element is to increase the retention time of food particles in the gut (Sibley 1981). In filter feeders, this increase may be the result of decreased filtration rates. Actually many theoretical and experimental studies have tried to demonstrate potential effects of food-nutrient richness on ingestion rate (reviewed by Yearsley et al. 2001). In Daphnia, results were contrasted with works showing either a negative, either a positive response of filtration rate with dietary P-deficiency, or even some work failing to detect any effects (reviewed by Darchambeau and Thys 2005). Mechanistic, adaptive arguments may be found for both positive and negative responses. The reduction of ingestion rate leads to higher residence time of food into the gut, improving intra-gut digestion and assimilation of the limiting biochemical compounds (Jumars 2000). By contrast, it has also been argued that increased filtration activity must lead to higher energy (thus $\mathrm{C}$ ) expenditures, reducing the $\mathrm{C}: \mathrm{P}$ ratio of net incorporated materials (Plath and Boersma 2001).

Thus, following the reasoning above, there could be contrasting foraging responses to cope with different food quality and quantity. Accurate evaluations of these processes and of their links seem useful to predict the direction of the ingestion and assimilation responses for herbivorous animals facing nutrient-deficient food. Yet there has been no attempt until now to develop a model of the effects of food quality [defined as the ratio between two essential elements] on ingestion, assimilation and growth simultaneously. Therefore, I apply a modified version of the Willow's model (Willows 1992) of feeding behaviour and physiology of filter-feeders to the case of stoichiometrically constrained homeostatic growth.

\section{Description of the model}

The initial model of Willows (1992) was designed for observing optimal behavioural (i.e. the filtration rate or gut residence time) and physiological (i.e. the secretion rate of digestive enzymes) responses of Mytilus edulis facing off variable dietary biomass and composition. I have adapted, applied and parameterised the model for Daphnia magna facing off variable food quantity and quality (in terms of C:P ratios). Homeostatic growth constrained the optimal responses. Note that all symbols and units are described in Table 1.

Willows (1992) assumed that the volume of food particles is reduced as they are digested and absorbed in the gut. The reduction over time of particle volume in the gut can thus be defined as a function of gut residence time $(\mathrm{T})$ and secretion rate of digestive enzymes (S). This function is of the same functional form as the absorption of element (Eq. 5), but, as Willows (1992), I assume that the reduction of particle volume can occur at a rate, $\mu$, lower than that for elemental absorption ( $\alpha$ and $\beta$; i.e. $\mu \leq \alpha=\beta)$. The time evolution of particle volume in the gut is thus given by (Willows 1992)

$\mathrm{V}(\mathrm{S}, \mathrm{t})=\mathrm{V}_{\mathrm{if}}+\left(\mathrm{V}_{\mathrm{i} 0}-\mathrm{V}_{\mathrm{if}}\right) \exp \left(-\mu \mathrm{St}^{2}\right)$

where $V_{i 0}$ and $V_{i f}$ are, respectively, the initial (undigested) volume of algal cell and the minimal potential (egested) volume of algal cell, and $\mathrm{t}$ is time. Hence, 
Table 1. Explanations of symbols used in the feeding homeostatic model, with values of parameters.

Optimized parameters

$\mathrm{S}_{\mathrm{N}} \quad$ Secretion rate of digestive enzymes hydrolyzing non-P compounds, $\mu \mathrm{g}$ atomic $\mathrm{C} \mathrm{h}^{-1}$

$\mathrm{S}_{\mathrm{P}} \quad$ Secretion rate of digestive enzymes hydrolyzing $\mathrm{P}$ compounds, $\mu \mathrm{g}$ atomic $\mathrm{C} \mathrm{h}^{-1}$

$\mathrm{T} \quad$ Gut residence time, $\mathrm{h}$

\section{Fixed parameters}

\begin{tabular}{|c|c|c|}
\hline$\alpha$ & Rate parameter for elemental absorption from non-P compounds, [ $\mu \mathrm{g}$ atomic $\mathrm{C}]^{-1} \mathrm{~h}^{-1}$ & 96.1 \\
\hline$\beta$ & Rate parameter for elemental absorption from $\mathrm{P}$ compounds, $[\mu \mathrm{g} \text { atomic } \mathrm{C}]^{-1} \mathrm{~h}^{-1}$ & 96.1 \\
\hline$\gamma$ & Resorption rate parameter for digestive enzymes, $\mathrm{h}^{-1}$ & 2.41 \\
\hline$\mu$ & Rate parameter for volume reduction of algal cell, $[\mu \mathrm{g} \text { atomic } \mathrm{C}]^{-1} \mathrm{~h}^{-1}$ & 24.0 \\
\hline $\mathrm{Q}_{\mathrm{T}}$ & Total carbon content of algal cell, $\mu \mathrm{g}$ atomic $\mathrm{C}$ cell ${ }^{-1}$ & $1.0610^{-6}$ \\
\hline$\rho$ & Fraction out total food $\mathrm{C}$ of refractory $\mathrm{C}$ (no units) & 0.10 \\
\hline$v$ & Fraction out total food $\mathrm{C}$ of $\mathrm{C}$ into non-P compounds (no units) & 0.30 \\
\hline$\pi$ & Fraction out total food $\mathrm{C}$ of $\mathrm{C}$ into potentially $\mathrm{P}$ compounds (no units) & 0.60 \\
\hline$\theta_{\mathrm{Z}}$ & Consumer $\mathrm{C}: \mathrm{P}$ ratio, $\mu \mathrm{g}$ atomic $\mathrm{C}[\mu \mathrm{g} \text { atomic } \mathrm{P}]^{-1}$ & 100 \\
\hline $\mathrm{V}_{\mathrm{g}}$ & Volume capacity of the gut, $\mathrm{ml}$ & $1.0810^{-5}$ \\
\hline $\mathrm{V}_{\mathrm{i} 0}^{\mathrm{s}}$ & Initial (undigested) volume of algal cell, $\mathrm{ml}$ & $6.5410^{-11}$ \\
\hline $\mathrm{V}_{\text {if }}$ & Minimum potential (egested) volume of algal cell, $\mathrm{ml}$ & $3.2710^{-11}$ \\
\hline $\mathrm{g}_{\mathrm{B}}$ & Basal maintenance rate, $\mu \mathrm{g}$ atomic $\mathrm{C} \mathrm{h}^{-1}$ & $3.8010^{-2}$ \\
\hline $\mathrm{g}_{1}$ & Filtration cost coefficient, $\mu \mathrm{g}$ atomic $\mathrm{C} \mathrm{h} \mathrm{ml}{ }^{-2}$ & $4.9310^{-5}$ \\
\hline $\mathrm{g}_{2}$ & Specific dynamic action coefficient & 0.2 \\
\hline
\end{tabular}

Variables

\begin{tabular}{|c|c|c|}
\hline $\mathrm{D}$ & Concentration of algal cells in the water, cells $\mathrm{ml}^{-1}$ & $3.9110^{3}-1.5610^{5}$ \\
\hline$\theta_{\mathrm{T}}$ & Total C:P ratio of algal cell, $\mu \mathrm{g}$ atomic $\mathrm{C}[\mu \mathrm{g} \text { atomic } \mathrm{P}]^{-1}$ & $20-800$ \\
\hline $\mathrm{P}_{\mathrm{T}}$ & Total $\mathrm{P}$ content of algal cell, $\mu \mathrm{g}$ atomic $\mathrm{P}$ cell ${ }^{-1}$ & $=\mathrm{Q}_{\mathrm{T}} / \theta_{\mathrm{T}}$ \\
\hline $\mathrm{Q}_{\mathrm{R}}$ & $\mathrm{C}$ content of refractory fraction, $\mu \mathrm{g}$ atomic $\mathrm{C}$ cell $^{-1}$ & $=\rho Q_{\mathrm{T}}$ \\
\hline $\mathrm{Q}_{\mathrm{N}}$ & $\mathrm{C}$ content of non-P compounds, $\mu \mathrm{g}$ atomic $\mathrm{C}$ cell $^{-1}$ & $=\mathrm{v} \mathrm{Q}_{\mathrm{T}}$ \\
\hline $\mathrm{Q}_{\mathrm{P}}$ & $\mathrm{C}$ content of $\mathrm{P}$ compounds, $\mu \mathrm{g}$ atomic $\mathrm{C}$ cell $^{-1}$ & $=\pi \mathrm{Q}_{\mathrm{T}}$ \\
\hline
\end{tabular}

\section{Rates}

$\mathrm{F} \quad$ Filtration rate, $\mathrm{ml} \mathrm{h}^{-1}$

$\mathrm{L}_{\mathrm{C}} \quad$ Egestion rate of digestive enzymes, $\mu \mathrm{g}$ atomic $\mathrm{C} \mathrm{h}^{-1}$

$\mathrm{B}_{\mathrm{C}} \quad$ Gross rate of absorption of $\mathrm{C}$ from feeding activity, $\mu \mathrm{g}$ atomic $\mathrm{C} \mathrm{h}^{-1}$

$\mathrm{R}_{\mathrm{C}} \quad$ Net rate of absorption of $\mathrm{C}$ from feeding activity, $\mu \mathrm{g}$ atomic $\mathrm{C} \mathrm{h}^{-1}$

$\mathrm{R}_{\mathrm{P}} \quad$ Net rate of absorption of $\mathrm{P}$ from feeding activity, $\mu \mathrm{g}$ atomic $\mathrm{P} \mathrm{h}^{-1}$

$\mathrm{D}_{\mathrm{C}} \quad$ Total rate of metabolic feeding cost, $\mu \mathrm{g}$ atomic $\mathrm{C} \mathrm{h}^{-1}$

$\mathrm{G}_{\mathrm{C}} \quad$ Net rate of $\mathrm{C}$ gain, $\mu \mathrm{g}$ atomic $\mathrm{C} \mathrm{h}^{-1}$

$\mathrm{G}_{\mathrm{P}} \quad$ Net rate of $\mathrm{P}$ gain, $\mu \mathrm{g}$ atomic $\mathrm{P} \mathrm{h}^{-1}$

$$
\int_{\mathrm{t}=0}^{\mathrm{t}=\mathrm{T}} \mathrm{V}(\mathrm{S}, \mathrm{t}) \mathrm{dt}
$$

represents the amount of digestive capacity utilized by a food particle (in $\mathrm{ml} \mathrm{h}^{-1}$ ). If $\mathrm{V}_{\mathrm{g}}$ is the volume capacity of the gut, then the filtration rate $(\mathrm{F})$ is derived as

$$
F=\frac{V_{g}}{D \int V(S, t) d t}
$$

where $\mathrm{D}$ is the density of food particles in the water.

Carbon (C) and $\mathrm{P}$ are combined in various compounds within the bodies of organisms. I thus distinguish food biochemical compounds into non-phosphorous and P-containing compounds. Assimilation over the gut wall of $\mathrm{P}$ compounds provides $\mathrm{C}$ and $\mathrm{P}$ to the animal, while assimilation of non-P compounds brings $C$ and no P. But considering that animals do not secrete gut enzymes specific to $\mathrm{P}$ compounds but more generally specific to large groups of biochemical compounds (e.g. secretion of lipase, protease, etc), I regroup in $\mathrm{P}$ compounds all protoplasmic compounds which may contain P (essentially lipids, nucleic acids, ATP, and Pi chains; $Q_{P}$ ) and in the non-P compounds we find molecules that never or very few contain P (essentially proteins and carbohydrates; $\mathrm{Q}_{\mathrm{N}}$ ). Both categories are hydrolyzed into the gut lumen by special gut enzymes: lipases, nucleases, nucleotidases and phosphatases for the $\mathrm{P}$ compounds, proteases and carbohydrases for the non-P compounds. I also distinguish the molecules that are never or uneasily assimilated and defined as refractory $\left(Q_{R}\right)$ : essentially the structural carbohydrates of the cell wall. Thus, total $\mathrm{C}$ of the food is divided into 3 fractions:

$\mathrm{Q}_{\mathrm{T}}=\mathrm{Q}_{\mathrm{N}}+\mathrm{Q}_{\mathrm{P}}+\mathrm{Q}_{\mathrm{R}}$

Let us define $\rho$ as the fraction out total $\mathrm{C}$ of the refractory $\mathrm{C}, \mathrm{v}$ as the fraction out total $\mathrm{C}$ of $\mathrm{C}$ into 
non-P compounds, $\pi$ as the fraction out total $\mathrm{C}$ of $\mathrm{C}$ into potentially $\mathrm{P}$ compounds, and $\theta_{\mathrm{T}}$ as the total $\mathrm{C}$ :P ratio of food $\left(\theta_{\mathrm{T}}=\mathrm{Q}_{\mathrm{T}} / \mathrm{P}_{\mathrm{T}}\right)$. I assume that $\rho, v$ and $\pi$ do not vary in function of food quality, and that the variation of $\theta_{T}$ reflects the variation in the richness of $\mathrm{P}$ in $\mathrm{P}$ compounds.

Thus, I use a model that allows absorption of $\mathrm{C}$ from food through the assimilation of $\mathrm{Q}_{\mathrm{N}}$ and/or of $Q_{\mathrm{P}}$ As I divide biochemical compounds into two digestible fractions, I also divide the gut enzymes into enzymes appropriate to the digestion of $\mathrm{P}$ compounds (lipases, nucleases, nucleotidases and phosphatases), with their own secretion rate $\left(S_{P}\right)$ and enzymes specific to the digestion of non-P compounds (proteases and carbohydrases), with their own secretion rate $\left(\mathrm{S}_{\mathrm{N}}\right)$. The gross absorption rate of $\mathrm{C}$ from ingested food $\left(\mathrm{B}_{\mathrm{C}}\right)$ increases with both the secretion rates of digestive enzymes $\left(S_{N}\right.$ and/or $\left.S_{P}\right)$ and gut residence time $(\mathrm{T})$ :

$$
\begin{aligned}
\mathrm{B}_{\mathrm{C}}= & \mathrm{FDQ}_{\mathrm{N}}\left[1-\exp \left(-\alpha \mathrm{S}_{\mathrm{N}} \mathrm{T}^{2}\right)\right] \\
& +\mathrm{FDQ}_{\mathrm{P}}\left[1-\exp \left(-\beta \mathrm{S}_{\mathrm{P}} \mathrm{T}^{2}\right)\right]
\end{aligned}
$$

where $\alpha$ and $\beta$ are the rate parameter for $\mathrm{C}$ absorption from, respectively, non-P and $\mathrm{P}$ compounds.

Part of the gut enzymes may be egested with nonassimilated food. The resorption by the gut wall of the secreted digestive enzymes themselves depends on gut residence time and may occur at its own rate $(\gamma)$. The rate of $\mathrm{C}$ lost by egestion of both classes of digestive enzymes that are not reabsorbed during passage through the gut is thus given by

$\mathrm{L}_{\mathrm{C}}=\left(\mathrm{S}_{\mathrm{N}}+\mathrm{S}_{\mathrm{P}}\right) \exp (-\gamma \mathrm{T})$

where $\gamma$ is the resorption rate parameter for both classes of gut enzymes. This loss of $\mathrm{C}$ is a first cost of the feeding process. The total rate $\left(\mathrm{R}_{\mathrm{C}}\right)$ at which $\mathrm{C}$ is truly (re)absorbed is thus equal to the sum between $\mathrm{C}$ ingested from food $\left(B_{C}\right)$ and $C$ reabsorbed from secreted gut enzymes:

$\mathrm{R}_{\mathrm{C}}=\mathrm{B}_{\mathrm{C}}+\left(\mathrm{S}_{\mathrm{N}}+\mathrm{S}_{\mathrm{P}}\right)-\mathrm{L}_{\mathrm{C}}$

Assimilation of $\mathrm{P}$ is achieved only by absorption of $\mathrm{P}$ compounds. As in these compounds, $\mathrm{C}$ and $\mathrm{P}$ are linked, the rate of $\mathrm{P}$ assimilation is equivalent to that for $\mathrm{C}$ from $\mathrm{P}$ compounds. But, as no amino acids contain P, I can postulate that the gut enzymes are not constituted of $P$ and that consequently there is no loss of $\mathrm{P}$ through the egestion of enzymes. Thus, the net rate at which $\mathrm{P}$ is absorbed $\left(R_{P}\right)$ is easily described by:

$\mathrm{R}_{\mathrm{P}}=\mathrm{FCP}_{\mathrm{T}}\left[1-\exp \left(-\beta \mathrm{S}_{\mathrm{P}} \mathrm{T}^{2}\right)\right]$

Note that $\left[1-\exp \left(-\beta \mathrm{S}_{\mathrm{P}} \mathrm{T}^{2}\right)\right]$ represents the assimilation efficiency of $\mathrm{P}$ compounds $\left(\mathrm{A}_{\mathrm{P}}\right)$. This is also by definition equivalent to the $\mathrm{P}$ assimilation efficiency. $\left[1-\exp \left(-\beta \mathrm{S}_{\mathrm{N}} \mathrm{T}^{2}\right)\right]$ represents the assimilation efficiency of non-P compounds $\left(\mathrm{A}_{\mathrm{N}}\right)$. The $\mathrm{C}$ assimilation efficiency $\left(\mathrm{A}_{\mathrm{C}}\right)$ can be calculated by the weighted average between $A_{P}$ and $A_{N}$ :

$\mathrm{A}_{\mathrm{C}}=v \mathrm{~A}_{\mathrm{N}}+\pi \mathrm{A}_{\mathrm{P}}$

As I have divided the secretion rate of digestive enzymes $\mathrm{S}$ into $\mathrm{S}_{\mathrm{N}}$ and $\mathrm{S}_{\mathrm{P}}$, I need to redefine $\mathrm{S}$ in Eq. 1 as the weighted average between $S_{N}$ and $S_{P}$ :

$\mathrm{S}=\nu \mathrm{S}_{\mathrm{N}}+\pi \mathrm{S}_{\mathrm{P}}$

In the model, metabolic costs of feeding are divided into three parts. First, there is the basal maintenance cost that includes essentially maintenance of osmotic potential. It is modelled as a constant rate. Second, there are the metabolic costs associated with beating of filtering appendages. In agreement with Lehman (1976), I assume that they are proportional to the square of the filtration rate. Third, there are the costs of biochemical processing of ingested food (the so-called specific dynamic action [SDA], Rubner 1902). This cost is proportional to the rate of (re)absorption that occurs, including components due to both food and resorption of the gut enzymes. The total metabolic feeding costs $\left(D_{C}\right)$ are then given by

$\mathrm{D}_{\mathrm{C}}=\mathrm{g}_{\mathrm{B}}+\mathrm{g}_{1} \mathrm{~F}^{2}+\mathrm{g}_{2} \mathrm{R}_{\mathrm{C}}$

where $g_{B}$ is the basal maintenance rate, and $g_{1,2}$ are the respective cost coefficients for the filtration process and the SDA (Table 1). After deducing these metabolic costs $\left(D_{C}\right)$ and the secretion rate of digestive enzymes $\left(S_{N}+\right.$ $\mathrm{S}_{\mathrm{P}}$ ) from the net rate of $\mathrm{C}$ absorption $\left(\mathrm{R}_{\mathrm{C}}\right)$, we obtain the net $C$ gain resulting from the feeding activity $\left(G_{C}\right)$ :

$\mathrm{G}_{\mathrm{C}}=\mathrm{R}_{\mathrm{C}}-\mathrm{D}_{\mathrm{C}}-\left(\mathrm{S}_{\mathrm{N}}+\mathrm{S}_{\mathrm{P}}\right)$

No metabolic costs are assumed for $\mathrm{P}$, leading to the definition of $P$ gain rate $\left(G_{P}\right)$ :

$G_{P}=R_{P}$

In my model, homeostatic growth of animals constrains the net rate of $\mathrm{C}$ growth:

$\mathrm{G}_{\mathrm{C}} \leq \mathrm{G}_{\mathrm{P}} \theta_{\mathrm{Z}}$

where $\theta_{Z}$ is the body atomic $\mathrm{C}: \mathrm{P}$ ratio of the herbivore. The gain in $\mathrm{P}$ may be proportionally higher than that for $\mathrm{C}$, because excess $\mathrm{P}$ will be simply excreted with a $\mathrm{C}$ cost already taken into account into the metabolization of $\mathrm{R}_{\mathrm{C}}$.

The optimization problem is to find values for the gut residence time (T) and secretion rates of both classes of digestive enzymes $\left(S_{N}\right.$ and $\left.S_{P}\right)$ that maximize $G_{C}$ in respect of the homeostatic constraint defined in Eq. 14. Optimization was realized for each set of food conditions (quantity and quality) with DONLP2 (Spellucci 1998), a sequential quadratic programming (SQP) algorithm implemented for nonlinearly, constrained optimization problems. Parameterisation was made for an adult Daphnia magna of $150 \mu \mathrm{g} \mathrm{C}$ (total body C) feeding on small Chlorella cells. Details of parameter estimation are given in Appendix 1. Optimizations were made for 
ranges of food concentration from 0.05 to $2 \mathrm{mg} \mathrm{C} 1^{-1}$ and food C:P ratios from 20 to 800 (molar ratios).

To see how the outcome of the model may vary over the range of plausible parameter values, I performed a sensitivity analysis. I perturbed each parameter to its lowest and highest plausible expected value in turn (Appendix 1), recording the response of the model, whilst holding all other parameters constant at their most likely point estimates listed in Table 1 . The analysis was performed for each perturbation at $0.1,0.2,0.5$ and $2 \mathrm{mg} \mathrm{C} 1^{-1}$, each with a food C:P ratio of 100 and 800 . I computed mean squared relative error of $\mathrm{C}$ gain rate for each perturbation $[\Sigma \text { (residual/expected value })^{2}$ divided by 8]. I also recorded the effect of food quality on filtration rate and $\mathrm{C}$ and $\mathrm{P}$ assimilation efficiencies.

\section{Simulations}

A negative relationship was predicted between the food $\mathrm{C}: \mathrm{P}$ ratio and the optimal gut residence time (Fig. 1A). A strong increase of the optimal gut residence time was also observed as food quantity lowered below $0.2 \mathrm{mg} \mathrm{C}$ $1^{-1}$. The resulting optimal filtration rate varied with both food quantity and quality (Fig. 1B). Along the food concentration gradient, the filtration rate first increased to a maximum reached near $0.1 \mathrm{mg} \mathrm{C}^{-1}$ (by definition, the incipient limiting level, ILL), and then decreased until values around $2.66-4.34 \mathrm{ml} \mathrm{h}^{-1}$, in function of food quality. The filtration rate was stable for food quality from 20 to $\sim 320$ (Fig. 1B, 2), and increased as food became more P-deficient $(\mathrm{C}: \mathrm{P}>320)$. The food quantity did not influence the overall relative effect of food quality on filtration rate.

Positive relationships were predicted between the food $\mathrm{C}: \mathrm{P}$ ratio and the optimal secretion rate of both classes of digestive enzymes (Fig. 1C, D). The effect of the food quality was more pronounced for the secretion of enzymes appropriate to the digestion of $\mathrm{P}$ compounds $\left(\mathrm{S}_{\mathrm{P}}\right)$ than for enzymes linked to non-P compounds $\left(\mathrm{S}_{\mathrm{N}}\right)$. The result of the predicted relationships between the food $\mathrm{C}: \mathrm{P}$ ratio and ingestion and gut enzyme secretion rates is that $\mathrm{C}$ gross absorption increased along the $\mathrm{C}: \mathrm{P}$ gradient (Fig. 1E). The predicted higher secretion of enzymes associated with the reduction of gut residence time induced a higher egestion of digestive enzymes (Fig. 1F).

The total metabolic feeding cost (i.e. the basal maintenance cost, plus the filtration cost, plus the digestion cost) was predicted to increase strongly with food C:P ratio (Fig. 1G). The resulting growth rate was

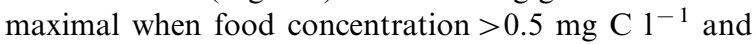
food C:P ratio $\leq 320$ (Fig. $1 \mathrm{H}$ ). Daphnia growth rate was null at food concentration $=0.05 \mathrm{mg} \mathrm{C}^{-1}$. Interestingly, the effect of food quality on growth rate is present for the whole range of food concentration $>0.05 \mathrm{mg} \mathrm{C}^{-1}$, but the C:P value between $\mathrm{P}$ and no-P limitation varied with food concentration (Fig. 3).

The evolution of $\mathrm{P}$ assimilation efficiency in function of $\mathrm{C}: \mathrm{P}$ ratio was predicted to vary with food concentration (Fig. 4A). It was predicted nearly invariant near the ILL and to decrease along the C:P gradient as food concentration $>0.1 \mathrm{mg} \mathrm{Cl}^{-1}$. Note nevertheless that the influence of $\mathrm{C}: \mathrm{P}$ ratio on $\mathrm{P}$ assimilation efficiency was very low. However, the $\mathrm{C}$ assimilation efficiency was much more influenced by the $\mathrm{C}: \mathrm{P}$ ratio (Fig. 4B). I calculated the net $\mathrm{C}$ absorption efficiency, i.e. the net balance of $\mathrm{C}$ absorbed by the feeding process, by $\mathrm{G}_{\mathrm{C}}$ / $\mathrm{FDQ}_{\mathrm{T}}$. It was still lower than the $\mathrm{C}$ assimilation efficiency because of $\mathrm{C}$ costs (Fig. 4C).

The optimization of $\mathrm{S}_{\mathrm{N}}, \mathrm{S}_{\mathrm{P}}$ and $\mathrm{T}$ in function of food quantity and quality was constrained by homeostatic growth. The higher total feeding $\mathrm{C}$ cost (Fig. 1G) plus the higher loss of $\mathrm{C}$ by egestion of digestive enzymes (Fig. 1F), both predicted with the increase of food C:P ratio, maintained an homeostatic but reduced growth (Fig. 1H). These predicted rises in $\mathrm{C}$ costs were essentially linked, at high food concentration, to the increase of gut enzyme egestion (Fig. 5A). On the other hand, at biomass near the ILL, it was the filtration cost and the SDA that were mainly responsible of total costs and of its rise with the increase of food $\mathrm{C}: \mathrm{P}$ ratio (Fig. 5B).

In the model, two strategies are compared to achieve the homeostatic growth of Daphnia: the differential assimilation of $\mathrm{P}$ and non- $\mathrm{P}$ compounds, and the increase of the $\mathrm{C}$ dispenses leading to a more equilibrated $\mathrm{C}: \mathrm{P}$ ratio of incorporated material. The simulations showed that both strategies were simultaneously used by Daphnia. The difference between the $\mathrm{P}$ assimilation and the $\mathrm{C}$ assimilation efficiencies increased along the food C:P gradient (Fig. 4A-B), and there was positive relationships between rates of $\mathrm{C}$ loss by the feeding process and the food $\mathrm{C}: \mathrm{P}$ ratio (Fig. $1 \mathrm{~F}-\mathrm{G}$ ). Very interesting is to know whether each strategy might be sufficient, and if not, when each one is preferentially used.

The preferential assimilation of $\mathrm{P}$ compounds might be sufficient until the $\mathrm{C}: \mathrm{P}$ ratio of $\mathrm{P}$ compounds is below the consumer $C: P$ ratio. For Daphnia $\left(\theta_{\mathrm{Z}}=100\right)$, and with a fraction of $\mathrm{C}$ into $\mathrm{P}$ compounds $v=0.6$, this limit is equal to 167. Above this limit, even if all the $\mathrm{C}$ is assimilated from the $\mathrm{P}$ compounds, the assimilated C:P ratio will be higher than that of the consumer. Therefore, the second strategy must necessarily be active when food $\mathrm{C}: \mathrm{P}$ ratio is above this limit. In the model, the $\mathrm{C}$ costs that may vary during the feeding process are the $\mathrm{C}$ lost from egested gut enzymes $\left(\mathrm{L}_{\mathrm{C}}\right)$, the filtration cost $\left(\mathrm{g}_{1} \mathrm{~F}^{2}\right)$ and the SDA $\left(g_{2} R_{C}\right)$. By definition, they are all increased by enhanced feeding activity. Consequently, when the food C:P ratio $>167$, only an increase of the feeding process, and of the associated costs, may lead to a more 

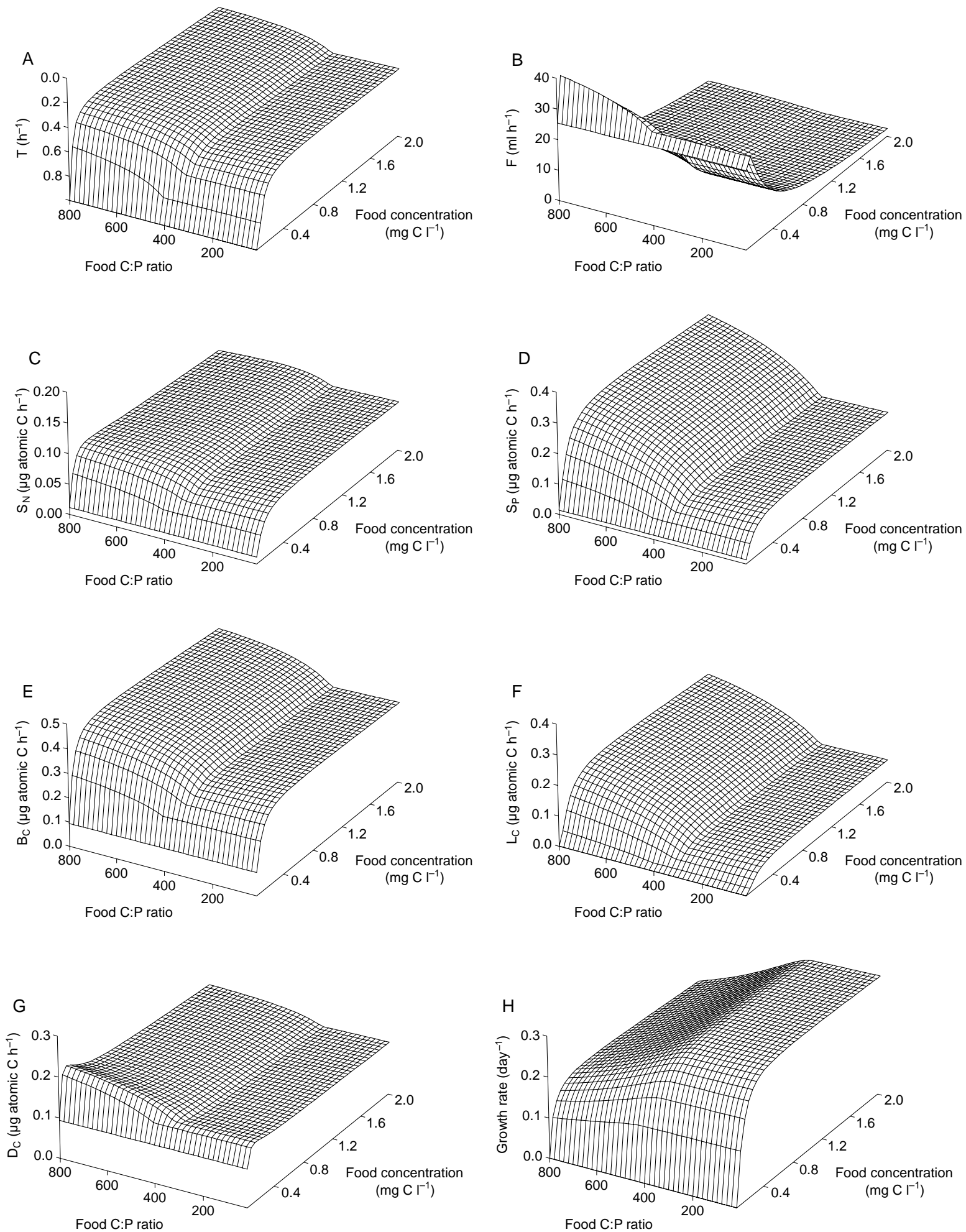

Fig. 1. Modelled effect of food quantity and quality (C:P ratios) on (A) optimal gut residence time (note that the scale is inversed), (B) resulting filtration rate $\mathrm{F}$, (C) optimal production rate of digestive enzymes for non-P compounds $\mathrm{S}_{\mathrm{N}}$, (D) optimal production rate of digestive enzymes for $P$ compounds $S_{P},(E)$ gross rate of $C$ absorption $B_{C},(F)$ egestion rate of digestive enzymes $L_{C}$, $(G)$ total rate of metabolic feeding cost $\mathrm{D}_{\mathrm{C}},(\mathrm{H})$ growth rate (calculated by dividing the net rate of $\mathrm{C}$ gain $\mathrm{G}_{\mathrm{C}}$ by body $\mathrm{C}$ mass of an adult Daphnia magna, $10.3 \mu \mathrm{g}$ atomic C). All values of parameters are presented in Table 1 and discussed in Appendix. 


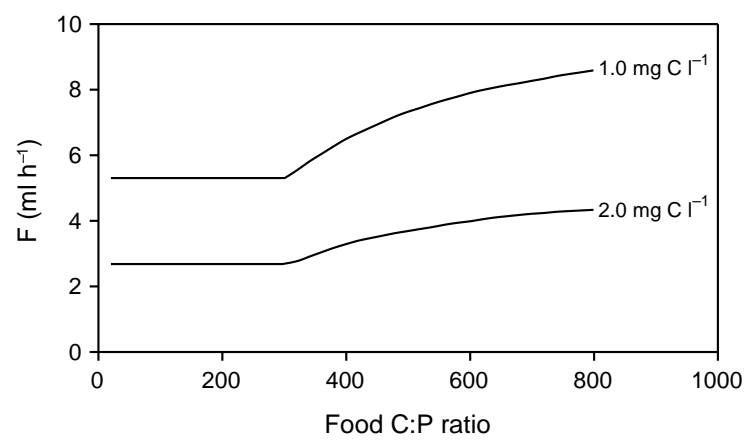

Fig. 2. Predicted optimal filtration rate, F, in function of food quantity and quality.

equilibrated C:P ratio of incorporated material. So, the Daphnia feeding response predicted by the model may be qualified as trivial. To circumvent this circularity problem between the model structure and its outputs, I add into Eq. 11 an additional term designed for the simple excretion or respiration of $\mathrm{C}$ assimilated in excess relative to P. So, Eq. 11 becomes

$\mathrm{D}_{\mathrm{C}}=\mathrm{g}_{\mathrm{B}}+\mathrm{g}_{1} \mathrm{~F}^{2}+\mathrm{g}_{2} \mathrm{R}_{\mathrm{C}}+\mathrm{g}_{\mathrm{S}}$

where $\mathrm{g}_{\mathrm{S}}$ is the excretion/respiration rate of $\mathrm{C}$ not linked to any feeding processes. I made simulations with Eq. 15 replacing Eq. 11, and with $g_{S}$ as a variable to optimize (as well as $\mathrm{T}, \mathrm{S}_{\mathrm{N}}$ and $\mathrm{S}_{\mathrm{P}}$, as before). So, $\mathrm{C}$ in excess had the possibility to be excreted/respired without an increase of the feeding process. Simulations were made for food quality varying from 20 to 800 and food quantity from 0.05 to $2 \mathrm{mg} \mathrm{C1}^{-1}$, as in Fig. 1. Results were that in all the simulations, $\mathrm{g}_{\mathrm{S}}$ stayed equal to 0 . The simple excretion of excess $\mathrm{C}$ was never used to achieve the

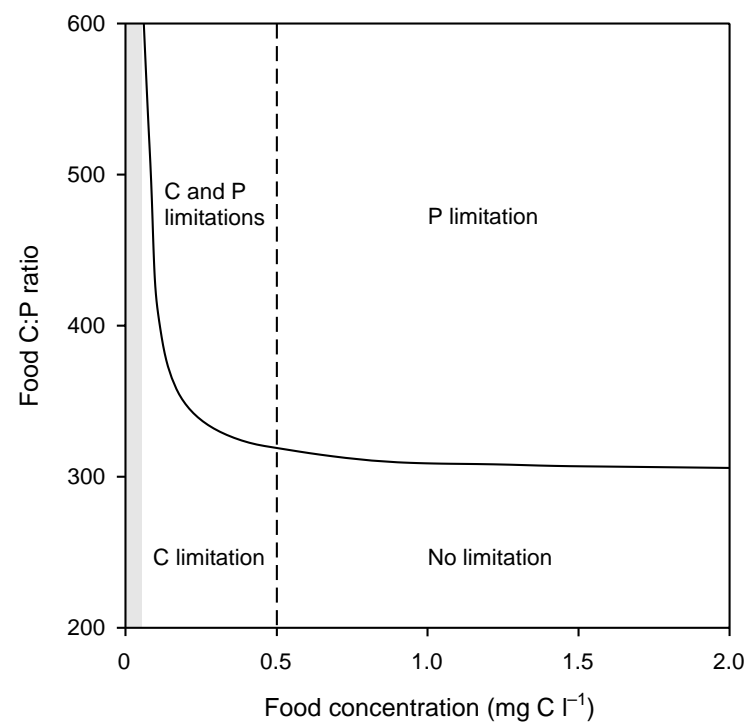

Fig. 3. Modelled boundaries between limitation vs no-limitation of food quantity (dashed line) and between limitation vs no-limitation of food quality (solid line) of Daphnia growth. The grey area represents Daphnia growth values $\leq 0$.

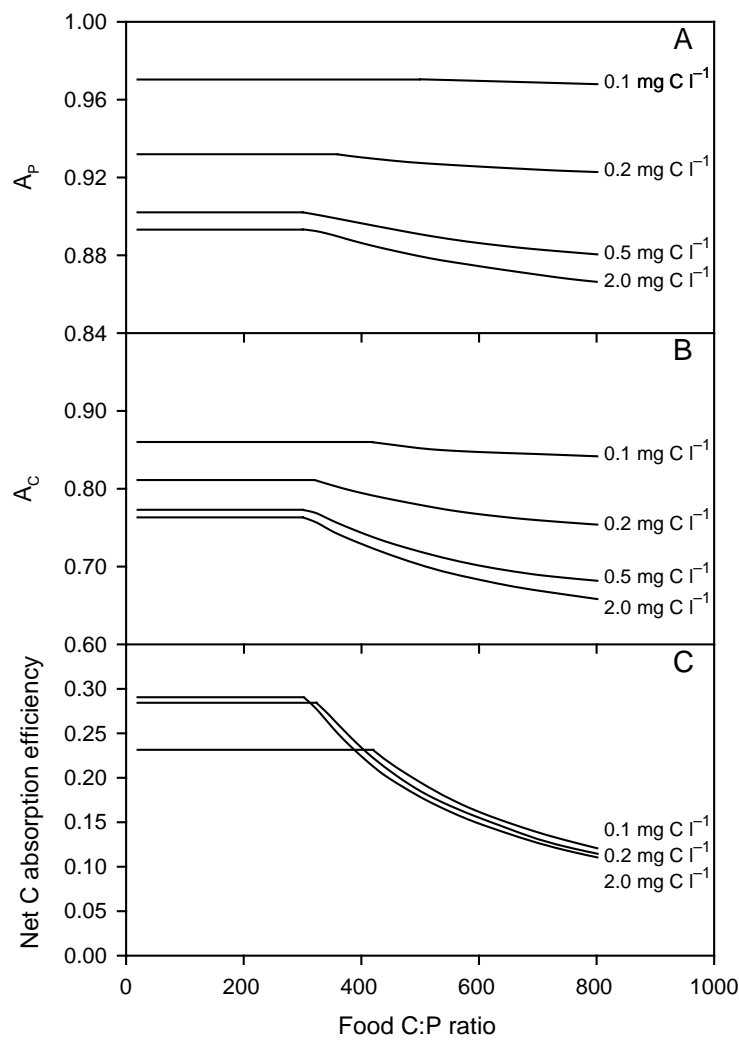

Fig. 4. Assimilation efficiency of (A) phosphorus, $A_{P}$, and (B) carbon, $A_{C}$, and $(C)$ net carbon absorption efficiency in function of food quantity and quality. Note the differences in the scale of the axis.

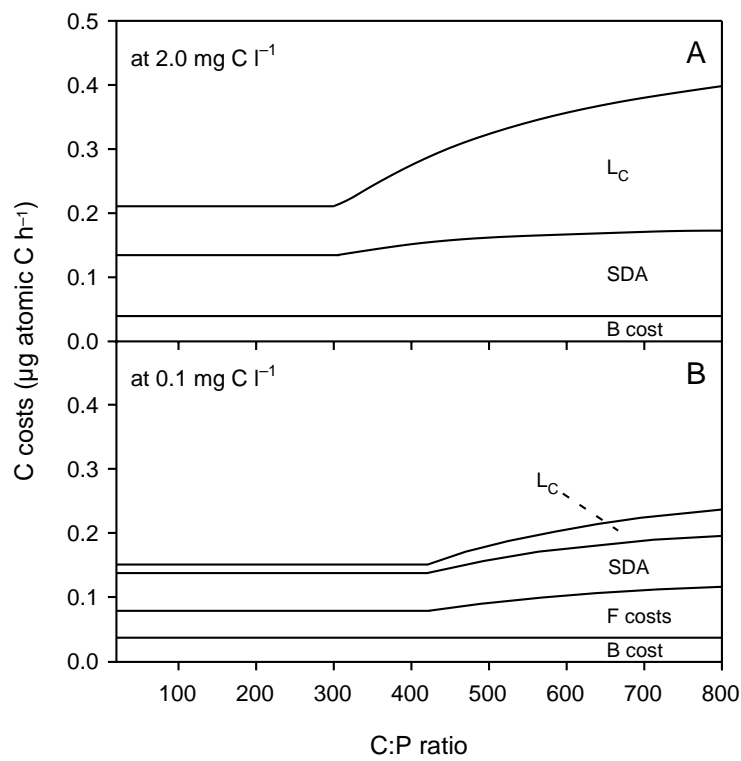

Fig. 5. Total feeding costs partitioned between the one due to the basal maintenance ( $\mathrm{B}$ cost, $\mathrm{g}_{\mathrm{B}}$ ), those due to the filtration rate $\left(F\right.$ costs, $\left.g_{1} F^{2}\right)$, the specific dynamic action (SDA, $\left.g_{2} R\right)$, plus the egestion of digestive enzymes (lost $\mathrm{S}, \mathrm{L}_{\mathrm{C}}$ ), (A) for food concentration of $2 \mathrm{mg} \mathrm{C}^{-1}$, (B) for food concentration of 0.1 $\mathrm{mg} \mathrm{C} 1^{-1}$. 
homeostatic growth. Optimal gut residence times, filtration rates and digestive enzyme secretion rates were thus strictly equivalent to those predicted by the model without direct excretion of $\mathrm{C}$ in excess, and figured in Fig. 1. The increase of the filtration rate when food is Pdeficient may thus be qualified as the optimal strategy, because it simultaneously speed up the ingestion of the deficient element and increase the $\mathrm{C}$ expenditures.

My model assumes that Daphnia can take advantage simultaneously of both responses, the behavioural one (optimization of the gut residence time) and the physiological one (regulation of the secretion of digestive enzymes). We may suppose that there is a time lag between both responses: the behavioural one is probably quicker than the physiological one. I simulated the effect of this unique, first response of a Daphnia submitted to a change in food quality by maintaining constant secretion rates of both classes of gut enzymes $\left(S_{\mathrm{N}}\right.$ and $\left.\mathrm{S}_{\mathrm{P}}\right)$. It may correspond to a short-term change to compare to a longterm acclimation illustrated previously. In Fig. 6, we observe the predicted filtration rate of a Daphnia acclimated to a food C:P ratio of 100 and then feeding on algae with higher C:P ratios. Only gut residence time was optimized and values of $S_{N}$ and $S_{P}$ maintained at the same values as for a C:P ratio of 100 . The short-term response of filtration rate to dietary P-deficiency was going to the same direction than the long-term response but amplified (Fig. 6A). $\mathrm{P}$ and $\mathrm{C}$ assimilation efficiencies were much more reduced than for the long-term adaptation, i.e. when $S_{N}$ and $S_{P}$ were also optimized (Fig. 6B, C). These largely decreased assimilation efficiencies led to growth rates lower than when $\mathrm{S}_{\mathrm{N}}$ and $S_{P}$ were also optimized (Fig. 6D).

The sensitivity analysis indicates which parameters strongly influenced the output of the model (Table 2). Net $\mathrm{C}$ gain rate was robust to perturbations of most parameters. The model was highly insensitive to values of parameters $\alpha, \beta$ and $\mu, 3$ parameters for which I do not have accurate estimates (Appendix 1). Likewise, values of the parameters linked to the estimation of $\mathrm{C}$ costs (i.e. $\gamma, \mathrm{g}_{1}, \mathrm{~g}_{\mathrm{B}}$ and $\mathrm{g}_{2}$ ) had no significant influence on resulting estimated $\mathrm{C}$ gain rates. However, the physical constraints of the digestive tract, which were parameterized by the respective volume of ingested algae (i.e. the algal length) and the gut volume $\left(\mathrm{V}_{\mathrm{g}}\right)$, directly influenced the $\mathrm{C}$ gain rate. Very logically, the $\mathrm{C}$ content of algae $\left(\mathrm{Q}_{\mathrm{T}}\right)$ and its digestibility ( $\left.\rho: v: \pi\right)$ also determined the $\mathrm{C}$ gain rate. Finally, and as expected, the C:P ratio of consumer, $\left(\theta_{Z}\right)$ influenced strongly its growth rate. The higher the consumer demand in $\mathrm{P}$, the lower was its growth rate in case of P-deficiency.

When looking at the general qualitative predictions of the model, we may note that each of the 104 combinations of parameter values of this sensitivity analysis (13 parameters $\times 2$ extreme values by parameter $\times 4$ food concentrations) led to optimal filtration rates higher at food $\mathrm{C}: \mathrm{P}$ ratio $=800$ than those predicted at food $\mathrm{C}: \mathrm{P}$ ratio $=100$. Likewise, the analysis always predicted a decrease of $\mathrm{C}$ assimilation efficiency as food quality is lowered (higher C:P ratio). The increase of the $\mathrm{P}$ assimilation efficiency was predicted in only 8 cases out of 104. It was the cases when the $\rho: v: \pi$ parameter was perturbed to its lowest and highest value (Table 2).

\section{Discussion}

My aim was to build up a realistic model of Daphnia feeding, able e.g. to correctly represent the well-known

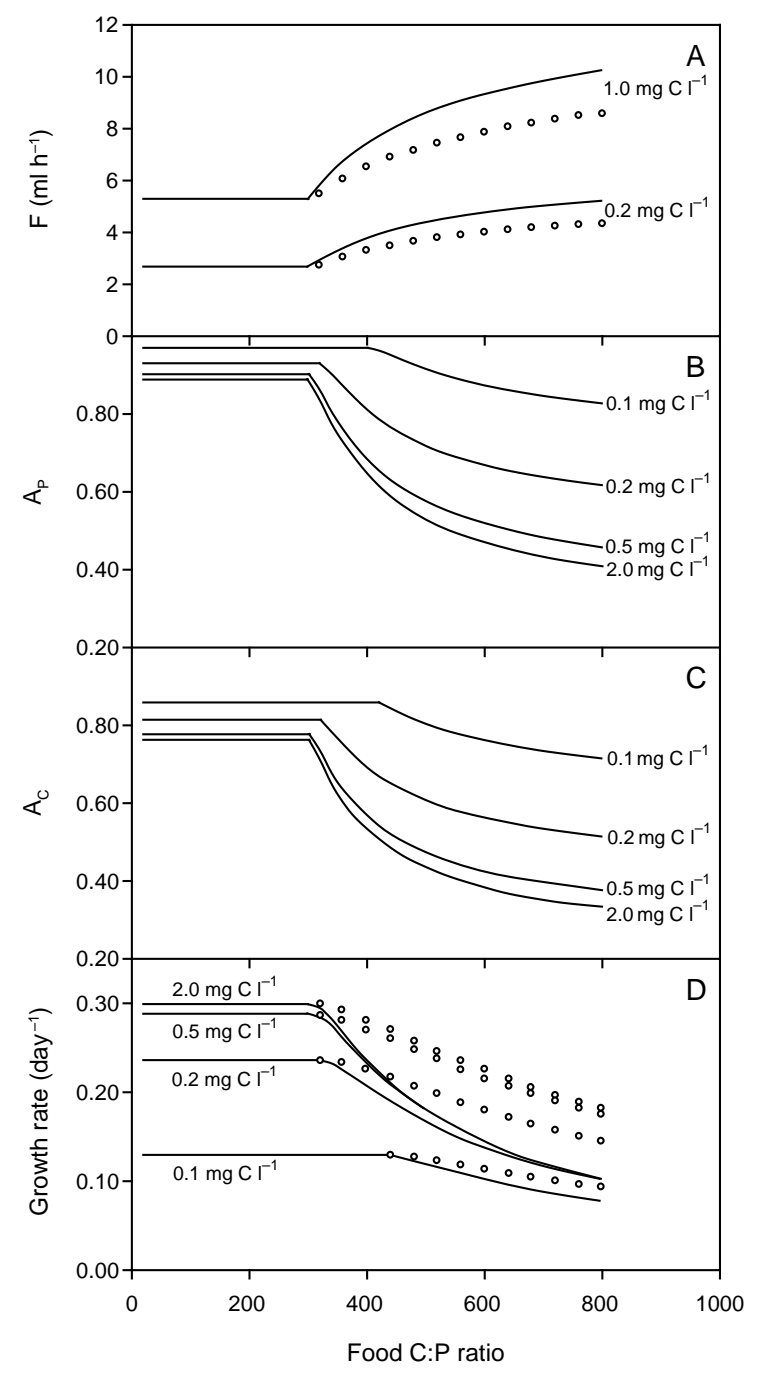

Fig. 6. Predicted responses to short-term change to $\mathrm{C}: \mathrm{P}$ ratio. Values of $S_{N}$ and $S_{P}$ are maintained to the ones predicted for a food C:P ratio of 100 . Only gut residence time is optimized in function of C:P ratio. (A) optimal filtration rate, $F$, (B) $\mathrm{P}$ assimilation efficiency, $A_{P},(C) C$ assimilation efficiency, $A_{C}$, (D) growth rate. In (A) and (D) respectively filtration and growth rates obtained by the optimization of $\mathrm{T}, \mathrm{S}_{\mathrm{N}}$ and $\mathrm{S}_{\mathrm{P}}$ are redrawn (open circles) for comparison. 
Table 2. Sensitivity analysis of the model. Each parameter was perturbed to its lowest and highest plausible expected value in turn

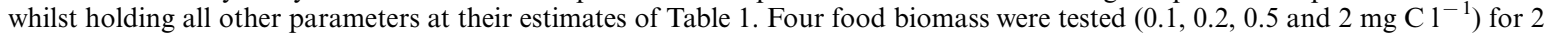
food C:P ratio (100 and 800). The mean squared relative error of $\mathrm{C}$ gain rate (MSRE) was computed for each perturbation. High value indicates that the model is sensitive to the parameter.

\begin{tabular}{|c|c|c|c|c|}
\hline Parameters & Value of parameter & MSRE & Value of parameter & MSRE \\
\hline 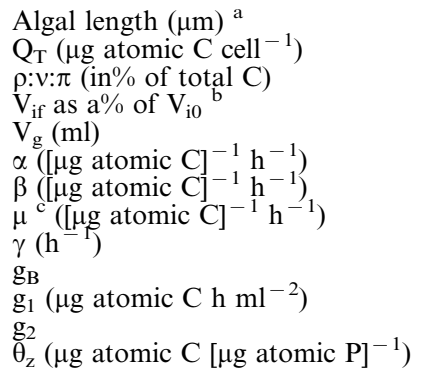 & $\begin{array}{l}1 \\
4.4910^{-7} \\
5: 60: 35 \\
25 \% \\
8.1010^{-6} \\
72.1 \\
72.1 \\
18.0 \\
1.81 \\
2.7910^{-2} \\
3.7010^{-5} \\
0.16 \\
90\end{array}$ & $\begin{array}{l}\mathbf{0 . 3 8 9} \\
\mathbf{0 . 9 7 5} \\
0.010 \\
0.001 \\
\mathbf{0 . 1 8 0} \\
0.003 \\
0.010 \\
0.000 \\
0.011 \\
0.008 \\
0.009 \\
0.004 \\
0.003\end{array}$ & $\begin{array}{l}10 \\
1.3610^{-6} \\
30: 40: 30 \\
75 \% \\
1.3510^{-5} \\
120.1 \\
120.1 \\
30.0 \\
3.02 \\
4.8210^{-2} \\
10.210^{-3} \\
0.24 \\
170\end{array}$ & $\begin{array}{l}0.041 \\
\mathbf{0 . 2 5 8} \\
\mathbf{0 . 1 8 2} \\
0.000 \\
\mathbf{0 . 2 1 0} \\
0.002 \\
0.008 \\
0.000 \\
0.009 \\
0.008 \\
0.006 \\
0.003 \\
\mathbf{0 . 0 8 5}\end{array}$ \\
\hline
\end{tabular}

Notes: (a) algal length is not a direct parameter of the model, but it affects $\mathrm{V}_{\mathrm{i} 0}, \mathrm{~V}_{\text {if }}$ and $\mathrm{Q}_{\mathrm{T}}$ (see Appendix 1), (b) perturbation of $\mathrm{V}_{\text {if }}$ also affects $\mathrm{V}_{\mathrm{g}}$, (c) perturbation of $\mu$ also affects $\mathrm{V}_{\mathrm{g}}$.

kinetics of filtration rate in function of food concentration. I based my model on the structure proposed by the Willows' model (Willows 1992) that captures the physical constraint of food in the gut of a filter feeder. This model is based on the well-developed gut-reactor theory (Penry 1993). My improvements of this model were designed to predict the influence of both food quantity and stoichiometric quality on a filter feeder such as a Daphnia magna with a homeostatic elemental content. In the literature, three levels of responses are generally attributed to organisms dealing with elemental imbalances. The regulation may occur separately or simultaneously at the ingestion, assimilation and excretion levels (Sterner and Hessen 1994, Frost et al. 2005). The two first levels are closely linked because of physiological constraints. The present model investigates these links with a stoichiometric perspective.

As food elements are combined into different biochemical fractions, elements cannot be assimilated alone. Following the original idea of Anderson and Hessen (1995) for copepods with C and nitrogen, I separated food biochemical components into P and non-P compounds. However contrary to Anderson and Hessen (1995) for the C:N ratio, I have considered that the C:P ratio of $\mathrm{P}$ compounds is not fixed, and that the total $\mathrm{C}: \mathrm{P}$ ratio reflects the richness in $\mathrm{P}$ of $\mathrm{P}$ compounds. I postulate that these two fractions can be assimilated from the gut lumen separately from each other. Indeed, in plants, $\mathrm{P}$ is essentially found in nucleic acids (RNA and DNA), in P-lipids (e.g. membrane phosphoglycerides), in some esters (e.g. glucose 6-phosphate, ATP) and sometimes substantially in polyphosphate bodies (Bieleski and Ferguson 1983). In this model, I assume that the secretion into the gut lumen of digestive enzymes specific to $\mathrm{P}$ compounds (e.g. nucleases, lipases) can be regulated by Daphnia. Other gut enzymes (e.g. proteases, carbohydrases) specifically deal with non-P compounds. The model thus allows us a distinct regula- tion of these two categories of gut enzymes, inducing separate assimilation of $\mathrm{P}$ compounds and non- $\mathrm{P}$ compounds. The $\mathrm{C}$ assimilation results from the assimilation of both types of compounds whereas $\mathrm{P}$ only comes from assimilation of $\mathrm{P}$ compounds.

Experimental evidences support the assumption that both type of compounds ( $\mathrm{P}$ and non- $\mathrm{P}$ compounds) are not equally assimilated leading to various $\mathrm{C}$ and $\mathrm{P}$ assimilation efficiencies. Assimilation efficiencies in copepods are correlated with the fraction in algal cytoplasm of the corresponding element (Reinfelder and Fisher 1991). DeMott et al. (1998) observed C and P assimilation rates in D. magna. They found differences between the coefficients of assimilation efficiency varying with food C:P ratio and going to 0.38 ( 0.95 for $\mathrm{P}$ and at the same time only 0.57 for C). Gulati et al. (2001) also observed significantly higher assimilation efficiencies for $\mathrm{P}$ than for $\mathrm{C}$ in $D$. galeata feeding on a cyanobacterium. Anderson (1994) with the data of Head (1992) calculated very large differences in the assimilation efficiencies of $\mathrm{C}$, proteins, carbohydrates and lipids in herbivorous marine copepods. And finally Tang and Dam (1999), reinterpreting the data of 7 studies on assimilation in copepods, put in evidence that the assimilation efficiency of non- $\mathrm{N}$ compounds is lower than that of $\mathrm{N}$ compounds. So, differential assimilation of biochemical compounds seems to exist in herbivorous crustacean zooplankters. However, interestingly, at a higher trophic level, Lehman (1993) found no difference between $\mathrm{C}$ and $\mathrm{P}$ assimilation efficiencies in Bythotrephes cederstroemi, a cladoceran predator of invertebrates.

The model also assumes that the consumer can regulate its secretion of gut enzymes in function of food concentration and nutrient-richness. So far, this second assumption is supported by few experimental results. We know that copepods can control their total digestive enzymatic activity as a function of food concentration (Mayzaud and Poulet 1978, but see 
discussion in Mayzaud et al. 1998). In Daphnia, it has been demonstrated that the secretion of acid and alkaline phosphatases depends on both food type and food status of the animal (Wynne and Gophen 1981). I must underline here that the single observation of variable assimilation efficiencies as a function of food quality is not a proof of digestive enzyme regulation because assimilation is primarily under the control of gut residence time and therefore of ingestion rate.

Another important assumption made in the model is that a significant part of the digestive enzymes is lost via egestion. At present there is no evidence that it may occur or not in daphniids. Nevertheless this process has been largely documented in mussels (Hawkins and Bayne 1985, Hawkins et al. 1986, 1990, Bayne et al. 1988), and suggested as an important energy and nutrient loss in insects (Slansky and Feeny 1977).

The final output of the model is the gain of $\mathrm{P}$ and $\mathrm{C}$ by the animal. Feeding and digestive costs were added for $\mathrm{C}$ in order to obtain the net gain of C. No analytical solution was performed for this system of non-linear equations. Homeostatic growth constrains the three nonfixed parameters: gut residence time $(\mathrm{T})$, secretion rate of digestive enzymes for $\mathrm{P}$ compounds $\left(\mathrm{S}_{\mathrm{P}}\right)$, and secretion rate of digestive enzymes for non-P compounds $\left(S_{N}\right)$. The three parameters were optimized for each set of food characteristics (quantity and quality) by an SQP algorithm implemented by DONLP2 (Spellucci 1998). As I did not only want to produce qualitative predictions about the direction of regulations used by the consumer, but also to observe their respective magnitude in a realistic range of food conditions, I have tried to use the most realistic parameter estimates from the literature.

Two situations were tested: one corresponding to a long-term acclimation of changes in food characteristics (gut residence time and secretion rates of both classes of gut enzymes could be optimized) and the other to a short-term where just gut residence time was able to be adjusted (secretion rates of both classes of gut enzymes are maintained constant).

In long-term acclimation, i.e. when gut residence time and secretion of digestive enzymes for non-P and $\mathrm{P}$ compounds absorption were optimized as a function of food quality (C:P ratio) and quantity, the model predicts a double response of Daphnia to food nutrient deficiency: first, a reduction of the gut residence time (leading to an increase of filtration and ingestion rates) observed when food quality is low (high C:P ratio; Fig. 1A, B, 2), and second, a concomitant higher secretion of gut enzymes that partly counteracts the reduced gut residence time (Fig. 1C, D). Both responses, even simultaneously present, do not avoid a significant reduction in growth rate of the consumer feeding on nutrient-deficient diet (Fig. 1H).

Some of these predictions have already been confirmed by experimental data. Many experiments showed an important decrease of Daphnia growth rate as feeding on P-deficient algae. Causes of this limitation were initially largely debated (reviewed by Gulati and DeMott 1997, Sterner and Schulz 1998). But ultimately Urabe et al.'s (1997) and DeMott's (1998) results support the elemental $\mathrm{P}$ hypothesis.

Testing the Daphnia filtration prediction against experimental evidences causes difficulties due to the modification of cell-wall thickness observed in some nutrient-deficient algae (Van Donk and Hessen 1993, 1995). This complicates the discussion of results about long-term clearance rates, as studied by Sterner et al. (1993), Sterner and Smith (1993), Van Donk et al. (1997) and Lürling and Van Donk (1997). More interestingly, Plath and Boersma (2001) observed the feeding-appendage beat rates of D. magna. They found that the rate was not influenced by food quality along a C:P range of $\sim 30$ to $\sim 250$, but significantly increased as food became more and more P-deficient (C:P of 360 and 690), actually mimicking the model prediction. Unfortunately, Plath and Boersma did not distinguish in their experiment the direct effect of food quality from an indirect effect via the observed reduced growth and thus lower size of animals at the moment of beat rate measurements. Moreover the feeding-appendage beat rate is not stricto sensu a measure of ingestion. Many particles may be captured but not ingested. However, Darchambeau and Thys (2005) observed that the in situ ingestion rate of a natural Daphnia galeata population was positively correlated with the seston C:P ratio. This last evidence on a natural, well-acclimated Daphnia population confirms the reality of the model prediction about the filtration response.

The rise of the feeding activity does not seem a common response of animals to low food quality (Yearsley et al. 2001). We may suspect that the ingestion response to food quality is species-dependent, and above all depends on the deficient element. In general, gutreactor theory predicts that when food is deficient in carbohydrates, ingestion rate should decrease as food quality decreases (Jumars 2000). This result is supported by evidence from various experiments in insects (Jumars 2000), and nectarivorous birds (López-Calleja et al. 1997). However, when food is nutrient-deficient, the present model predicts an increase of the feeding rate. This result is supported by many evidences from experiments in insects (Slansky and Feeny 1977, Reynolds 1990) and in crustacean zooplankton (Darchambeau and Thys 2005). Energy-lacking food may probably not induce an increase of food intake, while the deficiency of structural elements may be compensated by increased ingestion.

To my knowledge, the predicted enzymatic response of Daphnia to food P-deficiency has not yet been tested. The effect of food quantity on copepod digestive enzyme secretion and activity is well known (above), but virtually 
no studies were made in Daphnia. In insects, factors responsible of gut enzyme secretion and activity were largely studied with contrasting results about the response to dietary nutrient deficiency (reviewed by Lehane et al. 1995, Ivanović et al. 2002).

The present model also predicts a higher egestion of gut enzymes as food quality decreases. As stated earlier, at present there is no experimental evidence that egestion of gut enzymes occurs or not in crustacean zooplankters. Note nevertheless that Darchambeau et al. (2003) observed high release of endogenous C-rich compounds in D. magna. This excretion of endogenous material was significantly increased as animals were fed with Pdeficient algae. One can wonder whether this higher excretion may correspond to the higher egestion of gut enzymes predicted by the present model. Further promising researches are required in this area.

Finally, the model predicts a reduction in $\mathrm{P}$ and $\mathrm{C}$ assimilation efficiencies, and especially in the short-term simulations where the secretion rates of gut enzymes are not optimized (Fig. 6B, C). This is a result of the reduced gut residence time. This may correspond to a transient, first response of Daphnia to food P-deficiency. This prediction may adequately explain some observations made by DeMott et al. (1998). In one of their experiments, they submitted during $48 \mathrm{~h}$ juveniles of $D$. magna to a range of food $\mathrm{C}: \mathrm{P}$ ratio from 80 to 900 at a biomass level of $0.5 \mathrm{mg} \mathrm{C} 1^{-1}$. Both $\mathrm{C}$ and $\mathrm{P}$ assimilation efficiencies (calculated over the 2-day period) were shown to decrease along the $\mathrm{C}: \mathrm{P}$ ratio, with a higher decrease for $\mathrm{C}$ than for $\mathrm{P}$. Their observations really mimic my results figured in Fig. $6 \mathrm{~B}$ and $\mathrm{C}$. However, they did not observe, in the same experiment, any influence of food C:P ratio on weight-specific ingestion rate, maybe due to the relative high variance of some of their measurements. Note that the responses of both $\mathrm{C}$ and $\mathrm{P}$ assimilation efficiencies along the $\mathrm{C}: \mathrm{P}$ gradient were investigated only in the study of DeMott et al. (1998). So these processes require further experimental observations, particularly for natural populations well acclimated to P-deficiency.

From model results, we may conclude that the optimal strategy to maintain its body elemental homeostasis for a Daphnia facing a dietary nutrient deficiency combines the simultaneous increase of ingestion and gut enzyme secretion rates. From a stoichiometric point of view, the increase of the feeding process might be interpreted as a way to simultaneously increase the assimilation of the deficient element $(\mathrm{P})$ and the expenditures of the element in excess $(\mathrm{C})$, leading to a reduced and equilibrated $\mathrm{C}: \mathrm{P}$ ratio of the incorporated material. Nevertheless, as all $\mathrm{C}$ costs were in the model linked with the feeding process, the positive response of the ingestion rate is quite trivial, as being the only one leading to an equilibrated $\mathrm{C}: \mathrm{P}$ ratio of assimilated material. Yet, results from Darchambeau et al.'s experiments on Daphnia respiration and excretion
(Darchambeau et al. 2003) may suggest the existence of stoichiometrically regulated outgoing fluxes without a link with the feeding rate. They indeed observed higher respiration and organic carbon excretion rate of Daphnia submitted to low quality food $(\mathrm{C}: \mathrm{P}=400)$ than those for animals feeding on $\mathrm{P}$-sufficient algae $(\mathrm{C}: \mathrm{P}=80)$, whereas no effects of the food quality were observed in the assimilation rate. So, in these experiments, respiration/excretion rates were increased while the feeding process was maintained constant. Apart from time scale effects (in these experiments, ingestion, assimilation and respiration/excretion were unfortunately not measured with the same time scale), no reasonable mechanistic explanations were given for these observations. So it is reasonable to suspect the existence in Daphnia of stoichiometrically regulated $\mathrm{C}$ outgoing fluxes. To investigate the opportunity of this $\mathrm{C}$ disposal as an optimal strategy, some simulations were made with a slightly modified version of the model. An additional term figuring a $\mathrm{C}$ excretion/respiration rate without link with the feeding process was added to Eq. 11 (Eq. 15). It gave to the consumer the opportunity of reducing the $\mathrm{C}: \mathrm{P}$ ratio of assimilated material without increasing $\mathrm{C}$ feeding costs. Results were that, in all the simulations made, this expenditure rate was always maintained equal to 0 . The achievement of the consumer $\mathrm{C}: \mathrm{P}$ ratio was always obtained by both a differential assimilation of $\mathrm{P}$ and non-P compounds, and the disposal of excess $\mathrm{C}$ via feeding regulated rates (the egestion of digestive enzymes, the digestion of assimilated material [the SDA], and at low food concentration the direct filtration $\mathrm{C}$ costs; Fig. 5A-B). This observation revokes these $\mathrm{C}$ stoichiometrically regulated outgoing fluxes as an optimal strategy for achieving the homeostatic growth. Observations made by Darchambeau et al. (2003) either resulted from short-term adaptations leading to a nonoptimal, transient response to the recent change in food quality (as already considered in their discussion), or are the proof that the physiological adaptations modelled in this work are unlikely or insufficient.

My model takes into account three energy (C) costs attached to the feeding process: the direct filtration cost, the SDA, and the egestion of digestive enzymes. At low food concentration, the egestion of digestive enzymes and the direct filtration cost were mainly responsible for the rise of the total feeding cost observed as $\mathrm{C}: \mathrm{P}$ ratio increases (Fig. 5B). This relative high cost of appendage beating $(27-33 \%$ of total costs, in function of food C:P ratio) is at the basis of the important reduction of filtration rate predicted by the model and experimentally observed in daphniids at low food concentration ( < ILL; Philippova and Postnov 1988). Conversely, at high food concentration, the predicted high secretion rates of gut enzymes raise the contribution of their egestion in the total cost, while the direct contribution of the filtration cost is rather low ( $\sim 0.2 \%$ of total costs). 
Thus, even when the direct contribution of filtration cost in total cost is low, the whole feeding process creates higher costs, maintaining the role of feeding in the dissipation of excess C. Plath and Boersma (2001) already suggested the role of filtration cost to reduce the $C: P$ ratio of assimilated material, while the expected low cost of filtration made this suggestion few realistic. It was the reason why Plath and Boersma (2001) also called upon the potential egestion of digestive enzymes as a process that can increase $\mathrm{C}$ losses as gut residence time decreases. The present study emphasizes the role of each feeding cost in the disposal of excess $\mathrm{C}$, with respective contributions varying with food quantity.

In conclusion, my results highlight the importance of nutrient availability in resources for a consumer success. An optimal feeding strategy for a nutrient-deficient consumer has been defined. It involves a concomitant increase of the feeding rate and secretion of gut enzymes. Predictions of the model must now be tested.

Acknowledgements - I would like to thank Benoit Colson for his help in the optimization process and AMPL writing. I am also grateful to Dag Hessen for his helpful suggestions, William DeMott who kindly reviewed an earlier draft of this manuscript, and Jean-Pierre Descy for his continuous support during the whole process of this study.

\section{References}

Anderson, T. R. 1994. Relating C:N ratios in zooplankton food and faecal pellets using a biochemical model. - J. Exp. Mar. Biol. Ecol. 184: 183-199.

Andersen, T. R. and Hessen, D. O. 1991. Carbon, nitrogen, and phosphorus content of freshwater zooplankton. - Limnol. Oceanogr. 36: 807-814.

Anderson, T. R. and Hessen, D. O. 1995. Carbon or nitrogen limitation in marine copepods? - J. Plankton Res. 17: $317-$ 331.

Bayne, B. L. A., Hawkins, A. J. S. and Navarro, E. 1988. Feeding and digestion in suspension feeding bivalve molluscs: the relevance of physiological compensations. - Am. Zool. 28: 147-159.

Belkoura, M., Benider, A. and Dauta, A. 1997. Effects of temperature, light intensity and growth phase on the biochemical composition of Chlorella sorokiniana Shihira \& Krauss. - Ann. Limnol. 33: 3-11.

Bieleski, R. L. 1973. Phosphate pools, phosphate transport, and phosphate availability. - Annu. Rev. Plant Phys. 24: 225252.

Bieleski, R. L. and Ferguson, I. B. 1983. Physiology and metabolism of phosphate and its compounds. - In: Läuchli, A. and Bieleski, R. L. (eds), Encyclopedia of plant physiology, new series, vol. $15 \mathrm{~A}$, Inorganic plant nutrition. Springer-Verlag, pp. $422-449$.

Bohrer, R. N. and Lampert, W. 1988. Simultaneous measurement of the effect of food concentration on assimilation and respiration in Daphnia magna Straus. - Funct. Ecol. 2: $463-$ 471.

Brendelberger, H., Herbeck, M., Lang, H. et al. 1986. Daphnia's filters are not solid walls. - Arch. Hydrobiol. 107: 197-202.

Buchanan, B. B., Gruissem, W. and Jones, R. L. 2000. Biochemistry and molecular biology of plants. - Am. Soc. Plant Physiol., Rockville, MD, USA.
Darchambeau, F. and Thys, I. 2005. In situ filtration responses of Daphnia galeata to changes in food quality. - J. Plankton Res. 27: 227-236.

Darchambeau, F., Færøvig, P. J. and Hessen, D. O. 2003. How Daphnia copes with excess carbon in its food. - Oecologia 136: $336-346$.

DeMott, W. R. 1998. Utilization of a cyanobacterium and a phosphorus-deficient green alga as complementary resources by daphnids. - Ecology 79: 2463-2481.

DeMott, W. R., Gulati, R. D. and Siewertsen, K. 1998. Effects of phosphorus-deficient diets on the carbon and phosphorus balance of Daphnia magna. - Limnol. Oceanogr. 43: 11471161.

Elser, J. J., Fagan, W. F., Denno, R. F. et al. 2000. Nutritional constraints in terrestrial and freshwater food webs. - Nature 408: $578-580$.

Eppley, R. W., Reid, F. M. and Strickland, J. D. H. 1970. The ecology of the plankton off La Jolla, California, in the period April through September 1967-pt. III. Estimates of phytoplankton crop size, growth rate and primary production. - Bull. Scripps Inst. Oceanogr. 17: 33-42.

Frost, P. C., Evans-White, M. A., Finkel, Z. V. et al. 2005. Are you what you eat? Physiological constraints on organismal stoichiometry in an elementally imbalanced world. - Oikos 109: $18-28$.

Gosselain, V., Hamilton, P. B. and Descy, J.-P. 2000. Estimating phytoplankton carbon from microscopic counts: an application for riverine systems. - Hydrobiologia 438: 75-90.

Gulati, R. D. and DeMott, W. R. 1997. The role of food quality for zooplankton: remarks on the state-of-the-art, perspectives and priorities. - Freshwater Biol. 38: 753-768.

Gulati, R. D., Bronkhorst, M. and Van Donk, E. 2001. Feeding in Daphnia galeata on Oscillatoria limnetica and on detritus derived from it. - J. Plankton Res. 23: 705-718.

Hawkins, A. J. S. and Bayne, B. L. 1985. Seasonal variation in the relative utilization of carbon and nitrogen by the mussel Mytilus edulis: budgets, conversion efficiencies and maintenance recquirements. - Mar. Ecol. Prog. Ser. 25: 181-188.

Hawkins, A. J. S., Bayne, B. L., Mantoura, R. F. C. et al. 1986. Chlorophyll degradation and absorption throughout the digestive system of the blue mussel Mytilus edulis. - J. Exp. Mar. Biol. Ecol. 96: 213-223.

Hawkins, A. J. S., Navarro, E. and Inglesias, J. I. P. 1990. Comparative allometrics of gut content, gut passage time and metabolic faecal loss in Mytilus edulis and Cerastoderma edule. - Mar. Biol. 105: 197-204.

Head, E. J. H. 1992. Comparison of the chemical composition of particulate material and copepod faecal pellets at stations off the coast of Labrador and in the Gulf of St. Lawrence. - Mar. Biol. 112: 593-600.

Hessen, D. O. 1990. Carbon, nitrogen, and phosphorus status in Daphnia at varying food conditions. - J. Plankton Res. 12: $1239-1250$.

Hessen, D. O. 1997. Stoichiometry in food webs-Lotka revisited. - Oikos 79: 195-200.

Hessen, D. O. and Lyche, A. 1991. Inter- and intraspecific variations in zooplankton elemental composition. - Arch. Hydrobiol. 121: 343-353.

Hessen, D. O. and Andersen, T. 1992. The algae-grazer interface: feedback mechanisms linked to elemental ratios and nutrient cycling. - Arch. Hydrobiol. Beih. Ergebn. Limnol. 35: $111-120$.

Hessen, D. O. and Faafeng, B. A. 2000. Elemental ratios in freshwater seston; implications for community structure and energy transfer in food webs. - Arch. Hydrobiol. Adv. Limnol. 55: 349-363.

Ivanović, J., Đordević, S., Ilijin, L. et al. 2002. Metabolic response of cerambycid beetle (Morimus funereus) larvae to starvation and food quality. - Comp. Biochem. Physiol. A 132: $555-566$.

Jumars, P. A. 2000. Animal guts as ideal chemical reactors: maximising absorption rates. - Am. Nat. 155: 527-543. 
Lehane, M. J., Blakemore, D., Williams, S. et al. 1995. Regulation of digestive enzyme levels in insects. - Comp. Biochem. Physiol. B 110: 285-289.

Lehman, J. T. 1976. The filter-feeder as an optimal forager, and the predicted shapes of feeding curves. - Limnol. Oceanogr. 21: $501-516$.

Lehman, J. T. 1980. Nutrient recycling as an interface between algae and grazers in freshwater communities. - In: Kerfoot, W. C. (ed.), Evolution and ecology of zooplankton communities. Univ. Press of New England, Hanover, NH, USA, pp. $251-263$.

Lehman, J. T. 1993. Efficiencies of ingestion and assimilation by an invertebrate predator using $\mathrm{C}$ and $\mathrm{P}$ dual isotope labeling. - Limnol. Oceanogr. 38: 1550-1554.

López-Calleja, M. V., Bozinovic, F. and Martínez del Rio, C. 1997. Effects of sugar concentrations on hummingbird feeding and energy use. - Comp. Biochem. Physiol. A 118: $1291-1299$.

Lürling, M. and Van Donk, E. 1997. Life history consequences for Daphnia pulex feeding on nutrient-limited phytoplankton. - Freshwater Biol. 38: 693-709.

Mayzaud, P. and Poulet, S. 1978. The importance of the time factor in the response of zooplankton to varying concentrations of naturally occurring particulate matter. - Limnol. Oceanogr. 23: 1144-1154.

Mayzaud, P., Tirelli, V., Bernard, J. M. et al. 1998. The influence of food quality on the nutritional acclimation of the copepod Acartia clausi. - J. Mar. Syst. 15: 483-493.

McMahon, J. W. 1970. A tracer study of ingestion and metabolic cylcing of iron in Daphnia magna. - Can. J. Zool. 48: 873-878

McMahon, J. W. and Rigler, F. H. 1965. Feeding rate of Daphnia magna Straus in different foods labeled with radioactive phosphorus. - Limnol. Oceanogr. 10: 105-113.

Melzer, A. and Steinberg, Ch. 1983. Nutrient cycling in freshwater ecosystems. - In Lange, O. L., Nobel, P. S., Osmond, C. B. et al. (eds), Encyclopedia of plant physiology, new series, vol. 12D, Physiological plant ecology IV, Ecosystem processes: mineral cycling, productivity and man's influence. Springer-Verlag, pp. 47-84

Olsen, Y. and Østgaard, K. 1985. Estimating release rates of phosphorus from zooplankton: model and experimental verification. - Limnol. Oceanogr. 30: 844-852.

Parker, R. A. and Olsen, M. I. 1966. The uptake of inorganic phosphate by Daphnia schødleri Sars. - Physiol. Zool. 39: $53-65$.

Penry, D. L. 1993. Constraints on diet selection. - In: Hughes, R. N. (ed.), Diet selection: an interdisciplinary approach to foraging behaviour. Blackwell, pp. 32-55.

Philippova, T. G. and Postnov, A. L. 1988. The effect of food quantity on feeding and metabolic expenditure in Cladocera. - Int. Rev. Ges. Hydrobiol. 73: 601-615.

Plath, K. and Boersma, M. 2001. Mineral limitation of zooplankton: stoichiometric constraints and optimal foraging. - Ecology 82: 1260-1269.

Reinfelder, J. R. and Fisher, N. S. 1991. The assimilation of elements ingested by marine copepods. - Science 251: 794 796.

Reynolds, S. E. 1990. Feeding in caterpillars: maximizing or optimizing nutrient acquisition. - In: Mellinger, J. (ed.), Animal nutrition and transport processes. 1. Nutrition in wild and domestic animals, Karger, Basel, pp. 106-118.

Richman, S. 1958. The transformation of energy by Daphnia pulex. - Ecol. Monogr. 28: 273-291.

Rubner, M. 1902. Die Gesetze des Energieverbrauchs bei der Ernährung. - Franz Dauticke, Leipzig.
Schade, J., Kyle, M., Hobbie, S. et al. 2003. Stoichiometric tracking of soil nutrients by a desert insect herbivore. - Ecol. Lett. 6: 96-101.

Sibly, R. M. 1981. Strategies of digestion and defecation. - In: Townsend, C. R. and Callow, P. (eds), Physiological ecology: an evolutionary approach to resource use. Blackwell Scientific Publ, pp. 109-139.

Siderius, M., Musgrave, A., van den Hende, H. et al. 1996. Chlamydomonas eugametos (Chlorophyta) stores phosphate in polyphosphate bodies. - J. Phycol. 32: 402-409.

Slansky, F. and Feeny, P. 1977. Stabilization of the rate of nitrogen accumulation by larvae of the cabbage butterfly on wild and cultivated food plants. - Ecol. Monogr. 47: 209228.

Spellucci, P. 1998. An SQP method for general nonlinear programs using only equality constrained subproblems. - Math. Program. 82: 413-448.

Sterner, R. W. and Smith, R. F. 1993. Clearance, ingestion and release of $\mathrm{N}$ and $\mathrm{P}$ by Daphnia obtusa feeding on Scenedesmus acutus of varying quality. - B. Mar. Sci. 53: $228-$ 239.

Sterner, R. W. and Hessen, D. O. 1994. Algal nutrient limitation and the nutrition of aquatic herbivores. - Annu. Rev. Ecol. Syst. 25: 1-29.

Sterner, R. W. and Schulz, K. L. 1998. Zooplankton nutrition: recent progress and a reality check. - Aquat. Ecol. 32: $261-$ 279.

Sterner, R. W. and Elser, J. J. 2002. Ecological stoichiometry: the biology of elements from molecules to the biosphere. - Princeton Univ. Press.

Sterner, R. W., Hagemeier, D. D., Smith, W. L. et al. 1993. Phytoplankton nutrient limitation and food quality for Daphnia. - Limnol. Oceanogr. 38: 857-871.

Sterner, R. W., Clasen, J., Lampert, W. et al. 1998. Carbon:phosphorus stoichiometry and food chain production. - Ecol. Lett. 1: $146-150$.

Tang, K. W. and Dam, H. G. 1999. Limitation of zooplankton production: beyond stoichiometry. - Oikos 84: 537-542.

Twiss, M. R. and Nalewajko, C. 1992. Influence of phosphorus nutrition on copper toxicity to three strains of Scenedesmus acutus (Chlorophyceae). - J. Phycol. 28: 291-298.

Urabe, J. and Watanabe, Y. 1990. Influence of food density on respiration rate of two crustacean plankters, Daphnia galeata and Bosmina longirostris. - Oecologia 82: 362-368.

Urabe, J., Clasen, J. and Sterner, R. W. 1997. Phosphorus limitation of Daphnia growth: is it real? - Limnol. Oceanogr. 42: 1436-1443.

Van Donk, E. and Hessen, D. O. 1993. Grazing resistance in nutrient-stressed phytoplankton. - Oecologia 93: 508-511.

Van Donk, E. and Hessen, D. O. 1995. Reduced digestibility of UV-B stressed and nutrient-limited algae by Daphnia magna. - Hydrobiologia 307: 147-151.

Van Donk, E., Faafeng, B. A., Hessen, D. O. et al. 1993. Use of immobilized algae for estimating bioavailable phosphorus released by zooplankton. - J. Plankton Res. 15: 761-769.

Van Donk, E., Lürling, M., Hessen, D. O. et al. 1997. Altered cell wall morphology in nutrient-deficient phytoplankton and its impact on grazers. - Limnol. Oceanogr. 42: 357364.

Willows, R. I. 1992. Optimal digestive investment: a model for filter feeders experiencing variable diets. - Limnol. Oceanogr. 37: 829-847.

Wynne, D. and Gophen, M. 1981. Phosphatase activity in freshwater zooplankton. - Oikos 37: 369-376.

Yearsley, J., Tolkamp, B. J. and Illius, A. W. 2001. Theoretical developments in the study and prediction of food intake. P. Nutr. Soc. 60: 145-156. 


\section{Appendix 1. Parameterization of the model}

Estimation of the initial (undigested) volume of algal cell $\left(\mathbf{V}_{\mathrm{i} 0}\right)$

I use the mean volume corresponding to a spherical Chlorella cell of $5-\mu \mathrm{m}$ diameter: $\mathrm{V}_{\mathrm{i} 0}=65.4 \mu \mathrm{m}^{3}=6.54$ $10^{-11} \mathrm{ml}$. For the sensitivity analysis, I consider an algal diameter of $1 \mu \mathrm{m}$ and $10 \mu \mathrm{m}$.

\section{Estimation of the minimum potential (egested) volume of algal cell $\left(V_{\text {if }}\right)$}

I postulate that the volume of algal cell may maximally be reduced to $50 \%$ of initial volume. As $\mathrm{V}_{\mathrm{i} 0}=65.4 \mu \mathrm{m}^{3}$, $\mathrm{V}_{\text {if }}=32.7 \quad \mu \mathrm{m}^{3}=3.27 \quad 10^{-11} \mathrm{ml}$. For the sensitivity analysis, I consider that $\mathrm{V}_{\text {if }}$ may vary from $25 \%$ to $75 \%$ of $\mathrm{V}_{\mathrm{i} 0}$.

\section{Estimation of the volume capacity of Daphnia gut $\left(\mathrm{V}_{\mathrm{g}}\right)$}

McMahon (1970) estimated the gut residence time of an adult D. magna feeding on Chlorella cells above the ILL: $\mathrm{T}=40$ min. McMahon and Rigler (1965) founded the maximal ingestion rate of the same Daphnia feeding on the same algae: $0.017 \mathrm{~mm}^{3} \mathrm{~h}^{-1}$. If I postulate a C assimilation efficiency of $70 \%$ after a gut residence time of $40 \mathrm{~min}$, we have that $\beta \mathrm{S}=\frac{-\ln (0.3)}{(40 / 60)^{2}}=2.71$ (Eq. 1d of Willows 1992). In a scenario where $\mu=0.25 \beta$ (below), we have $\mu \mathrm{S}=0.68$. If $\mathrm{V}_{\mathrm{if}}=50 \%$ of $\mathrm{V}_{\mathrm{i} 0}$, I can easily calculate the time-evolution of volume of ingested food during its journey throughout the gut by Eq. 8 of Willows (op. cit.). The total amount of food volume ingested during $40 \mathrm{~min}$ is equal to the total capacity of the gut: $\mathrm{V}_{\mathrm{g}}=1.08$ $10^{-5} \mathrm{ml}$. For the sensitivity analysis, I set $\mathrm{V}_{\mathrm{g}}$ to $-25 \%$ and $+25 \%$ of its mean value.

\section{Estimation of the total $C$ content of algal cell $\left(Q_{T}\right)$}

Eppley et al. (1970) estimated conversion factors between volume and $\mathrm{C}$ content of some algae. I use the factors for a non-diatomous spherical algae of 5- $\mu \mathrm{m}$ diameter: $\mathrm{Q}_{\mathrm{T}}=$ $1.0610^{-6} \mu \mathrm{g}$ atomic $\mathrm{C}$ cell $^{-1}$. For the sensitivity analysis, I found in Gosselain et al. (2000) a list of equations joining $\mathrm{C}$ content with cell biovolume. I used the two equations giving respectively the lower and the higher estimation of $\mathrm{C}$ content for a biovolume of 65.4 $\mu \mathrm{m}^{3}$.

\section{Estimation of the fractions of refractory $C(\rho)$ of $C$ into non- $P$ compounds $(v)$ and of $C$ into $P$ compounds $(\pi)$ out of total algal $C$}

There are very few indications of $\mathrm{C}$ content in cell wall of algae. In higher plants, cell wall constitutes $0.5-2 \%$ of fresh weight (Buchanan et al. 2000). If I consider the lowest value of this range, a dry weight:fresh weight ratio of $10 \%$, and that dry residuals are constituted at $50 \%$ of $\mathrm{C}$, I find that the cell wall in algae might contain $\sim 10 \%$ of total C. I thus define $\rho=0.1$. The respective fractions of carbohydrates and proteins in total biochemical compounds constitute, respectively, around $20 \%$ and $28 \%$ of total dry weight in Chlorella cells (Belkoura et al. 1997). Given the large amount of carbohydrates present in the cell wall, I define $v=0.3$, and by difference $\pi=0.6$. For the sensitivity analysis, I considered two contrasting situations about refractory $C: \rho: v: \pi$ ratios $=5: 60: 35$ and 30:40:30.

\section{Estimation of the filtration cost coefficient $\left(\mathrm{g}_{1}\right)$}

Brendelberger et al. (1986) modelized the theoretical energetic costs of filtration in Daphnia. For a large Daphnia (body size $=2.95 \mathrm{~mm}$ ), it was equal to $525 \mu \mathrm{J}$ $\mathrm{h}^{-1}$ when the filtration rate $=4.37 \mathrm{ml} \mathrm{h}^{-1}$. So, if respiration rate due to filtration $=\mathrm{g}_{1} \mathrm{~F}^{2}$, and assuming $5000 \mathrm{cal} \mathrm{g}^{-1} \mathrm{DW}$ in Daphnia (Richman 1958) and $45.1 \% \mathrm{C}$ in $\mathrm{DW}, \mathrm{g}_{1}=4.9310^{-5} \mu \mathrm{g}$ atomic $\mathrm{C} \mathrm{h} \mathrm{ml}{ }^{-2}$. For the sensitivity analysis, I set $g_{1}$ to $-25 \%$ and $+25 \%$ of its mean value.

\section{Estimation of the basal maintenance rate $\left(\mathrm{g}_{\mathrm{B}}\right)$}

Bohrer and Lampert (1988) estimated simultaneously respiration and assimilation rates for adult D. magna ( $\sim 275 \mu \mathrm{g} \mathrm{DW})$. The intercept on the y-axis of their regression of respiration on assimilation rates when feeding below the ILL (see their Fig. 5) gives us the respiration rate due to the basal maintenance cost plus filtration activity $\left(\mathrm{g}_{\mathrm{B}}+\mathrm{g}_{1} \mathrm{~F}^{2}\right): 1.68 \mu \mathrm{g} \mathrm{C} \mathrm{mg}{ }^{-1} \mathrm{DW}$ $\mathrm{h}^{-1}=3.8510^{-2} \mu \mathrm{g}$ atomic $\mathrm{C} \mathrm{h}^{-1}$. McMahon and Rigler (1965) estimated the maximal filtration rates for adult $D$. magna feeding on 11 different types of algae. The mean of these rates was equal to $2.9 \mathrm{ml}^{-1} \mathrm{ind}^{-1} \mathrm{~h}^{-1}$. So, if $\mathrm{g}_{\mathrm{B}}+\mathrm{g}_{1} \mathrm{~F}^{2}=3.8510^{-2} \mu \mathrm{g}$ atomic $\mathrm{C} \mathrm{h}^{-1}$, then $\mathrm{g}_{\mathrm{B}}=$ $3.8010^{-2} \mu \mathrm{g}$ atomic $\mathrm{C} \mathrm{h} \mathrm{ml}{ }^{-2}$. For the sensitivity analysis, I used the standard error of Bohrer and Lampert's estimation to calculate $95 \%$ confidence interval lower and higher limits. Combined with the lowest and highest estimations of filtration rates given by McMahon and Rigler (1965), it gives me the two realistic most extremes values of $g_{B}$.

\section{Estimation of the specific dynamic action coefficient} (g2)

The specific dynamic action is the cost associated with the biochemical transformation of ingested food (Rubner 1902). This coefficient corresponds to the slope of the regression of respiration on assimilation rates. I use the value found by Bohrer and Lampert (1988) for adult $D$. magna: $\mathrm{g}_{2}=0.20$. Note that Urabe and Watanabe (1990) 
found a very similar coefficient for D. galeata: 0.196 . For the sensitivity analysis, I set $\mathrm{g}_{2}$ to 0.16 and 0.24 .

\section{Estimation of the Daphnia C:P ratio $\left(\theta_{\mathrm{Z}}\right)$}

Although the $\mathrm{P}$ content of Daphnia is not strictly homeo-static and is linked to the C:P ratio of ingested food (Plath and Boersma 2001), I use a constant body $\mathrm{C}: \mathrm{P}$ ratio of D. magna equal to $100 \mu \mathrm{g}$ atomic $\mathrm{C}[\mu \mathrm{g}$ atomic $\mathrm{P}]^{-1}$. For the sensitivity analysis, I followed the two most extreme values of $\theta_{\mathrm{Z}}$ observed by Plath and Boersma: 90 and 170.

\section{Estimation of the resorption rate for digestive enzymes $(\gamma)$}

I postulate that $20 \%$ of the secreted digestive enzymes are not reabsorbed after a gut residence time of $40 \mathrm{~min}$. Thus, $\gamma=\frac{-\ln (0.10)}{(40 / 60)}=2.41 \mathrm{~h}^{-1}$. For the sensitivity analysis, I set $\gamma$ to $-25 \%$ and $+25 \%$ of its mean value.
Estimation of the rate parameters for elemental absorption from non-P compounds $(\alpha)$ for elemental absorption from $P$ compounds $(\beta)$ and for volume reduction of algal cell $(\mu)$

The model allows us to separately define the rate parameter $\mu$ for volume reduction of algal cell throughout the gut and the rate parameters $\alpha$ and $\beta$ for material absorption from enzymatic activities. I consider here a scenario where $\alpha=\beta=4 \mu$. Parameter values associated with enzymatic activity are less easy to constrain. $\mathrm{S}_{\mathrm{N}}, \mathrm{S}_{\mathrm{P}}, \mathrm{T}, \alpha(=\beta=4 \mu)$ were optimized by DONLP2 until predicted weight-specific growth rate at high food biomass equalled a commonly observed rate for Daphnia magna of $0.3 \mathrm{day}^{-1}$. The value observed in this scenario for $\alpha(=\beta)$ and $\mu$, respectively 96.1 and $24.0[\mu \mathrm{g} \text { atomic } \mathrm{C}]^{-1} \mathrm{~h}^{-1}$, was fixed as parameters for all other scenarii. For the sensitivity analysis, I perturb $\alpha, \beta$ and $\mu$ to $-25 \%$ and $+25 \%$ of their mean values. 